\title{
The impact of climate change on mediterranean intertidal communities: losses in coastal ecosystem integrity and services
}

\author{
Gianluca Sarà $\cdot$ Martina Milanese $\cdot$ Ivana Prusina $\cdot$ Antonio Sarà $\cdot$ Dror L. Angel $\cdot$ \\ Branko Glamuzina · Tali Nitzan · Shirra Freeman • Alessandro Rinaldi • Valeria Palmeri • \\ Valeria Montalto $\cdot$ Marco Lo Martire $\cdot$ Paola Gianguzza $\cdot$ Vincenzo Arizza $\cdot$ Sabrina Lo Brutto \\ Maurizio De Pirro $\cdot$ Brian Helmuth · Jason Murray $\cdot$ Stefano De Cantis · Gray A. Williams
}

Received: 1 March 2012/Accepted: 1 October 2012/Published online: 19 October 2012

(C) Springer-Verlag Berlin Heidelberg 2012

\begin{abstract}
As has been shown for other ecosystems, the ecological and socio-economic impacts of climate change on Mediterranean intertidal habitats are highly variable in space and time. We conducted field and laboratory measurements of cellular, ecophysiological and behavioural responses of selected intertidal invertebrates (mussels, gastropods and sponges) and completed a literature review to determine what is known of socio-economic consequences of these biological changes. Results suggest significant gaps in our knowledge that may impede a complete understanding of likely impacts (physical, biological and socio-economic) and that sufficient data for such an analysis are available only for mussels.
\end{abstract}

G. Sarà $(\bowtie) \cdot$ A. Rinaldi · V. Palmeri · V. Montalto ·

M. Lo Martire · P. Gianguzza

Dipartimento di Scienze della Terra e del Mare, University

of Palermo, Viale delle Scienze Ed. 16, 90128 Palermo, Italy

e-mail: gianluca.sara@unipa.it

M. Milanese · A. Sarà

Studio Associato Gaia, Genoa, Italy

I. Prusina · B. Glamuzina

Department of Aquaculture, University of Dubrovnik,

Dubrovnik, Croatia

D. L. Angel · T. Nitzan · S. Freeman

Recanati Institute for Maritime Studies, University of Haifa,

Haifa, Israel

A. Rinaldi

Dipartimento di Ecologia Marina, Università di Messina,

Messina, Italy

V. Arizza $\cdot$ S. Lo Brutto

Dipartimento di Biologia ambientale e Biodiversità,

University of Palermo, Palermo, Italy
Application of ecological models for native mussels Mytilaster minimus and invasive Brachidontes pharaonis bivalves indicates that the current distribution of these species is linked to the availability of food and local temperature. Choosing Israel as a case study, the study focused on the identification of ecosystem services and goods provided by the Mediterranean rocky intertidal and on the assessment of conservation approaches. Intertidal systems were poorly represented in the socio-economic literature, and there was low awareness of the value of these ecosystems among stakeholders. Subsequently, conservation efforts for intertidal communities were minimal. While climate change will very likely continue

M. De Pirro

Accademia Mare Ambiente, Monte Argentario, Italy

B. Helmuth

Department of Biological Sciences and Environment and Sustainability Program, University of South Carolina, Columbia, SC, USA

J. Murray

Moore School of Business and Environment and Sustainability

Program, University of South Carolina, Columbia, SC, USA

S. De Cantis

Dipartimento di Scienze Economiche, Aziendali e Finanziarie, University of Palermo, Palermo, Italy

G. A. Williams

The Swire Institute of Marine Science, The University

of Hong Kong, Hong Kong, China 
to impact these systems, our predictive capacity for the extent and locations of such impacts, and of any derived socio-economic consequences, remains limited.

Keywords Intertidal $\cdot$ Bioenergetic mechanistic modelling · Ecophysiology · Ecosystem services · Climate change $\cdot$ Invasive species $\cdot$ Mediterranean Sea

\section{Introduction}

Intertidal habitats, that is the zone between the high- and low-water marks along the world's coastlines and the interface between terrestrial and marine realms, are crucial for the provision of benefits to humans and have received considerable attention in the ecological as well as in the socio-economic literature (Nagelkerken et al. 2000; Wilson et al. 2005; Scyphers et al. 2011; Townsend et al. 2011). Research shows that mangrove systems and tidal flats play important roles in the marine environment in providing the services for human society (Barbier 2000; Aburto-Oropeza et al. 2008; Barbier et al. 2011). Key services provided by these systems include protection against physical disturbance, support to coastal and open-water fisheries and nutrient recycling (MEA 2005; Kareiva et al. 2011). Concerns about the possible consequences of future and ongoing climate change in the terrestrial environment and open oceans have been extended to intertidal habitats (Harley et al. 2006; Helmuth et al. 2006). It is expected that changing climate (especially temperature and circulation patterns) will significantly affect, in the next few decades, the survival and distribution of intertidal species (Somero 2010), and changes are already being observed in many regions of the world (Wethey and Woodin 2008; Jones et al. 2010). As a main consequence, changes in ecological community dynamics will eventually affect the provision of ecosystem services from these systems (Herr and Galland 2009; Barbier et al. 2011; Doney et al. 2012).

Recent research has also begun to address climate change and its impacts in the Mediterranean region (Mangos et al. 2010; Salomidi et al. 2012). This paper describes the results of the EU-funded project INTERMED, the goal of which was to understand and model the impact of climate change on the Mediterranean intertidal and to identify critical knowledge gaps that may impede our ability to predict these effects. The project considered both the ecophysiological and socio-economic components of climate change (Sarà et al. 2011a). The project included: (1) assessment of the existing knowledge base and gaps; (2) research to address the knowledge gaps identified; and (3) where possible, forecasts of the ecophysiological and socio-economic impacts of climate change in the Mediterranean region.

\section{Materials and methods}

Ecophysiological study

Research focused on selected organisms typical of the Mediterranean intertidal; specifically mussels, gastropods and sponges. The assessment of the existing knowledge base for each taxonomic group included a collation of relevant literature/databases and a meta-analytical review of the main effects of climate-change drivers on ecophysiological responses. This information was then used to design experiments intended to close knowledge gaps using field and laboratory measurements of cellular, ecophysiological and behavioural responses. Forecasts of climatechange effects were performed in cases where a sufficient amount of baseline information was available to develop adequate ecological models.

\section{Collation of relevant literature/databases and meta-analytical review}

On the basis of three earlier reviews (Scheiner and Gurevitch 2001; Sarà 2007a, b), a formal meta-analysis was made (following Sarà 2007a, b). The relatively advanced understanding of impacts of environmental effects on mussels allowed for the formulation of advanced, specific research questions. In contrast, only relatively general and preliminary questions could be conceived for gastropods and sponges given the lack of specific knowledge for these groups.

\section{Field and laboratory measurements of cellular, ecophysiological and behavioural responses}

This second step aimed to help close the knowledge gaps revealed by the systematic review process and involved several field and laboratory experiments. While specific questions varied according to species-specific differences, the single general question uniting the studies was whether variation in body temperatures of target Mediterranean intertidal invertebrates induced by predicted climate change would have measurable effects on ecophysiological responses. The latter were evaluated at various levels: from cellular to the whole-organismal level, and from populations to communities.

Thermal range of Mediterranean intertidal organisms Establishing the thermal range experienced by Mediterranean intertidal organisms was considered essential baseline information. Here, we specifically report data from the Central Mediterranean Sea. We deployed thermologgers (iButton iBCod 22L, http://www.alphamach.com; range: -40 to $70{ }^{\circ} \mathrm{C}$; precision: $\pm 0.5{ }^{\circ} \mathrm{C}$; memory: 2,048 values) to 
measure changes in thermal profiles in a variety of microhabitats in order to determine possible differences in the body temperature (BT) of animals living from the upper subtidal, the intertidal and supratidal zones. Thermologgers were deployed in several sites in northern Sicily and in Neretva Estuary (Croatia) from spring 2009 to winter 2010. Loggers were attached using waterproof glue and were programmed to record hourly data (8,760 temperature measurements per year per microhabitat).

Physiological responses to thermal stress Physiological responses to thermal stress were studied in bivalves (the native species Mytilus galloprovincialis, Mytilaster mini$m u s$ and the invasive Brachidontes pharaonis; Sarà et al. 2000), limpets (Patella rustica, P. aspera and P. caerulea), an intertidal snail (Echinolittorina punctata) and a sponge (Chondrilla nucula). These species were chosen because of their key roles in the Mediterranean intertidal, their availability and ease of manipulation. We tested target organisms at different combinations of both aerial (limpets and mussels) and submersed (all taxa) temperatures, within the ranges measured in the field and beyond (i.e. pushing organisms out of their normal ranges; Dong and Williams 2011). The methods followed the current approach for ecophysiological studies of intertidal invertebrates (Williams et al. 2011) to estimate: (1) the cellular response as expressed by heat shock proteins (HSP) in the laboratory and in the field (bivalves, snails); (2) feeding parameters such as food acquisition and assimilation rates (bivalves, sponges); (3) respiration rates (bivalves, sponges); and (4) heart beat rates (limpets, bivalves).

Cellular responses were evaluated in bivalves (B. pharaonis) and in the ubiquitous intertidal snail E. punctata by the quantification of HSP. The study on bivalves was performed in the laboratory at fixed temperatures from 5 to $35^{\circ} \mathrm{C}$ (at $5{ }^{\circ} \mathrm{C}$ increments) on six groups of 15 individuals from different sites of Northern Sicily. Fifteen E. punctata were collected at two rocky shores situated along the Mediterranean coast of Israel: Achziv, near Rosh Ha'nikra in the north and Palmachim, not far from Ashdod in the south. Animals were collected in the upper intertidal $(\sim 50 \mathrm{~cm}$ over the lower limit at low tide) during the mid-day. Proteins were extracted following the established protocols (Tomanek and Somero 2002), and the levels of heat shock proteins (HSP 70 and 90) were determined by western blot (Halpin et al. 2002).

Feeding rates were expressed as clearance rates (CR) for both bivalves and sponges (Sarà et al. 2008; Ezgeta-Balic et al. 2011). Respiration rates (RR) of the bivalves, B. pharaonis and M. minimus, and the sponge C. nucula were determined by placing individuals in glass respirometers (from 500 to 2,000 ml) containing air-saturated seawater, which was stirred by a magnetic stirrer bar beneath a perforated glass plate supporting the test organism (Sarà et al. 2008).

Heart beat rates (HBR) were measured in bivalves and limpets using a non-invasive cardioplethysmographic technique (Depledge and Andersen 1990; Dong and Williams 2011; Sarà and De Pirro 2011).

\section{Ecological modelling}

This phase of the work was based on mechanistic ecophysiological (biophysical, BP; Helmuth 1998, 1999) and bioenergetic (Dynamic Energy Budget, DEB; Kooijman 2010) models to estimate life history traits of target animals and to predict their distributions throughout study areas under current and future scenarios of increasing temperature in the context of climate change (see also Kearney et al. 2010, 2012; Kearney 2012; Sarà et al. 2011b, 2012). Given the lack of sufficient baseline information for most of the organisms examined in the present study (also combining results from systematic reviews and new primary data), modelling could only be performed on mussels.

The combined BP-DEB approach requires high-resolution data (at each location) of: (1) local water and air temperatures $\left(T_{\mathrm{a}}\right.$ and $\left.T_{\mathrm{w}},{ }^{\circ} \mathrm{C}\right)$, tidal amplitudes $(\mathrm{m})$, wind intensities $\left(\mathrm{m} \mathrm{s}^{-1}\right)$ and directions $\left({ }^{\circ}\right)$ [e.g. as hourly data measured by weather buoys (ISPRA; http://www.mareografico.it/ or thermologgers locally deployed for temperature)]; (2) solar irradiance (global sky-W $\mathrm{m}^{-2}$ ) calculated on an hourly basis as an average for each month of the year under clear skies (European Joint Research Centre—http://sunbird.jrc.it/pvgis); and (3) food density as expressed by suspended chlorophyll$a\left(\mu \mathrm{g}^{-1}\right)$, a reliable descriptor of food available for bivalves (Pusceddu et al. 1997; Sarà and Mazzola 2004; Sarà 2006, 2009) obtained at least as weekly or monthly frequencies (as from satellites-the European Joint Research Centerhttp://emis.jrc.ec.europa.eu/4_1_gismap.php).

BP-DEB models were run for the intertidal native species $M$. minimus and the Lessepsian invasive $B$. pharaonis using DEB standard parameters mostly derived from the experiments described above and as estimated by Palmeri (2011). We initially ran models for seven Italian localities along a Tyrrhenian latitudinal gradient (from $35^{\circ} \mathrm{N}-$ Lampedusa to $43^{\circ} \mathrm{N}$ Livorno-Northern Italy), two Croatian localities (Dubrovnik- $42^{\circ} \mathrm{N}$ and Split- $43^{\circ} \mathrm{N}$ ) and three Israeli sectors (southern $-31^{\circ} \mathrm{N}$, central $-32^{\circ} \mathrm{N}$ and northern $-33^{\circ} \mathrm{N}$ Israel). Then, we ran models to simulate a possible effect of climate change on the fitness of intertidal bivalves in the near future following the predictions of IPCC (2007). Most IPCC scenarios for the Mediterranean were based on the coupled atmosphere-ocean circulation models (AOGCMs) predicting an average increase of water temperature up to $2.5{ }^{\circ} \mathrm{C}$ by 2100 (Marcos and Tsimplis 2009). Accordingly, we ran DEB models simply by 
increasing the air and water temperatures by fixed quantities: +1.0 and $+2.5{ }^{\circ} \mathrm{C}$. This is, in fact, an oversimplification, as we increased the mean, but did not alter the variance of the data series. Irradiance and food densities at every location were also maintained at the present-day levels in the models, although an increase in eutrophication expected for the next decades could modify current levels of available food for secondary consumers (sensu Nixon 2009; Sarà et al. 2011c). Simulation outputs were: (1) the maximum total shell length (TL, cm) and the dry weight (g) achieved by bivalves as a function of body temperature under simulated conditions - 48 months from settling and (2) the Darwinian fitness as expressed by the total number of eggs produced per biomass unit and life span.

\section{Socio-economic study}

The socio-economic aspects of the study were originally designed to follow the same general framework as the ecophysiological approaches, namely assessing the existing knowledge base, contributing to closing the knowledge gaps identified, and forecasting the socio-economic consequences of climate change on the Mediterranean intertidal zone. However, the latter step could not be accomplished given the lack of a solid baseline (both ecophysiological and socio-economic) information necessary to build the model, irrespective of the advancements produced throughout the study herein described.

\section{Collation of relevant literature/databases and meta-analytical review}

Following a preliminary scoping of the published peerreviewed and grey literature, a systematic review relevant to the socio-economic study was carried out (presented in Milanese et al. 2011, and summarised, Table 1).

\section{Identification of ecosystem services in the Mediterranean intertidal zone}

A tentative list of ecosystem services and goods provided by the Mediterranean rocky intertidal was compiled (Milanese et al. 2011). We then focused on the assessment of conservation approaches specifically targeting this habitat, choosing Israel as a case study.

The assessment of conservation alternatives needs to be informed by an understanding of the ecosystem functions targeted by different alternatives, the conservation community's priorities and the direct and indirect costs of different alternatives. As the study was challenged by crucial information gaps (Milanese et al. 2011), the focus was on the generation of preliminary information needed to conduct more extensive studies. Specifically, the objective was to obtain input from key stakeholders in the conservation community. The study consisted of a set of structured and unstructured interviews with an emphasis on: (1) consultation to identify key stakeholders and conservation issues; (2) characterising the extent to which stakeholders identify the intertidal zone and its needs as distinct from the coastal and marine zones in conservation planning; (3) prioritising issues for the intertidal zone; and (4) assessing conservation alternatives.

\section{Results and discussion}

Ecophysiological studies

Collation of relevant literature and database and meta-analytical review

The current knowledge about the effects of climate change (here mainly identified with increased temperature) on selected target organisms is highly heterogeneous (synthesised in Table 1). Among the invertebrate groups, we addressed knowledge in this area appears relatively well established only for mussels (i.e. a baseline that is strong enough to inform and design experiments addressing specific and well-defined research questions). Thirty-one peerreviewed papers were ultimately used to report on the effect of temperature on the feeding behaviour and ecophysiological aspects of bivalves. This number of papers was considered sufficiently reliable to estimate the true effect as supported by a very high Rosenthal Index $(R=73,478.4$; Sarà 2007a).

The review process revealed that most bivalves did not display a specific scheme of altered feeding as a function of changing body temperatures, as would have been expected according to classic theory (Kooijman 2010) where the bigger the difference in temperature between two clearance rate (CR) values, the bigger is the expected effect size. Such a relationship was only valid for $B$. pharaonis and Hiatella sp. The lack of a clear relationship is probably due to the effect of secondary sources of variability affecting clearance rates (e.g. diet type, acclimation and sampling period). Our findings imply that although the relationship with temperature is expected to be clearly determined, data from the existing literature do not describe the phenomenon appropriately due to the significant experimental interference of other factors.

Sponges, via their filtration/pumping activity, are among the most important players in shallow benthic ecology (Bell 2008). Our review addressed this main trait, that is their filtration/pumping activity, with emphasis on the effect of temperature. A total of 506 literature sources were retrieved over the period 1892-2010, of which 68 included 


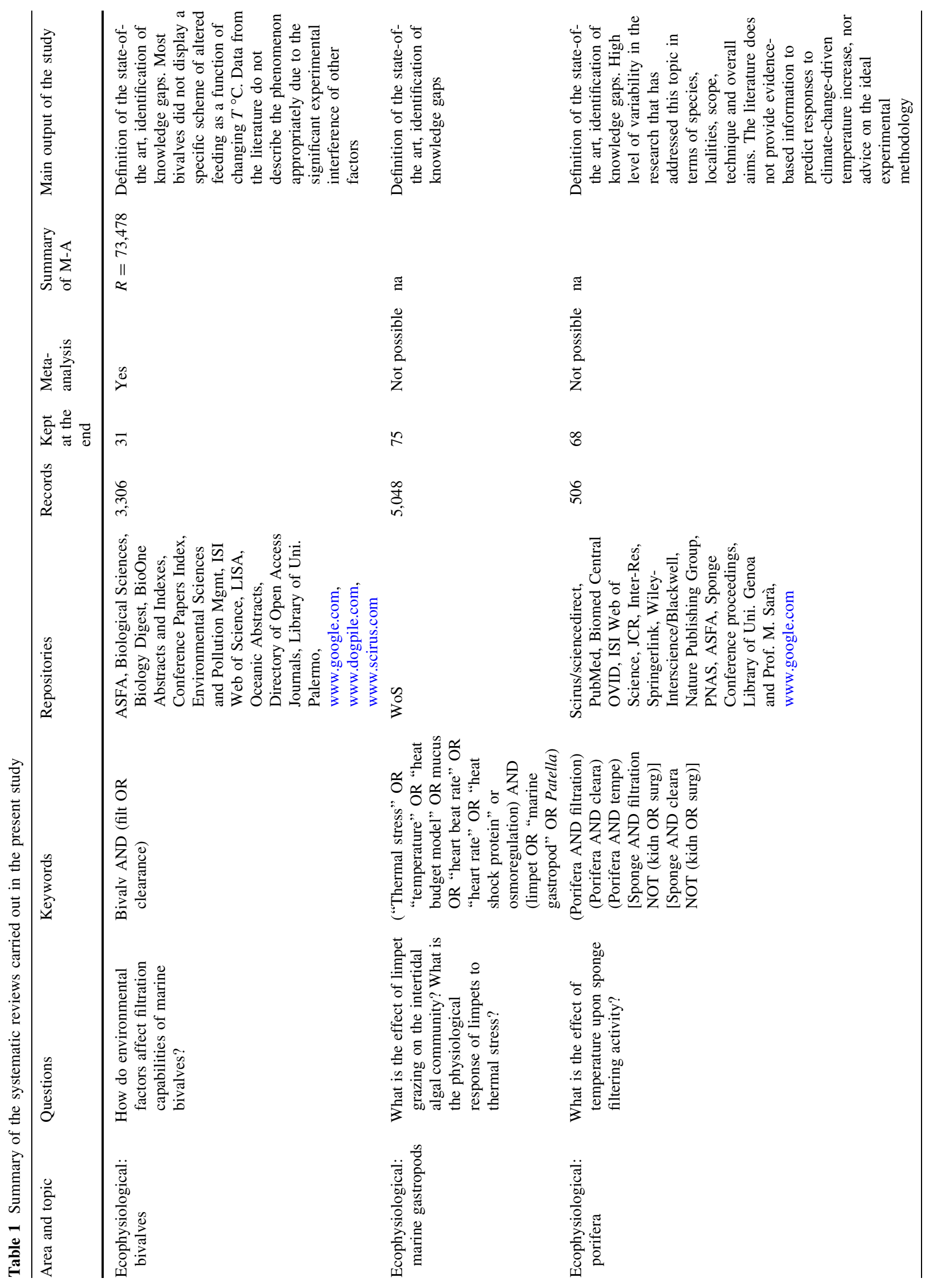




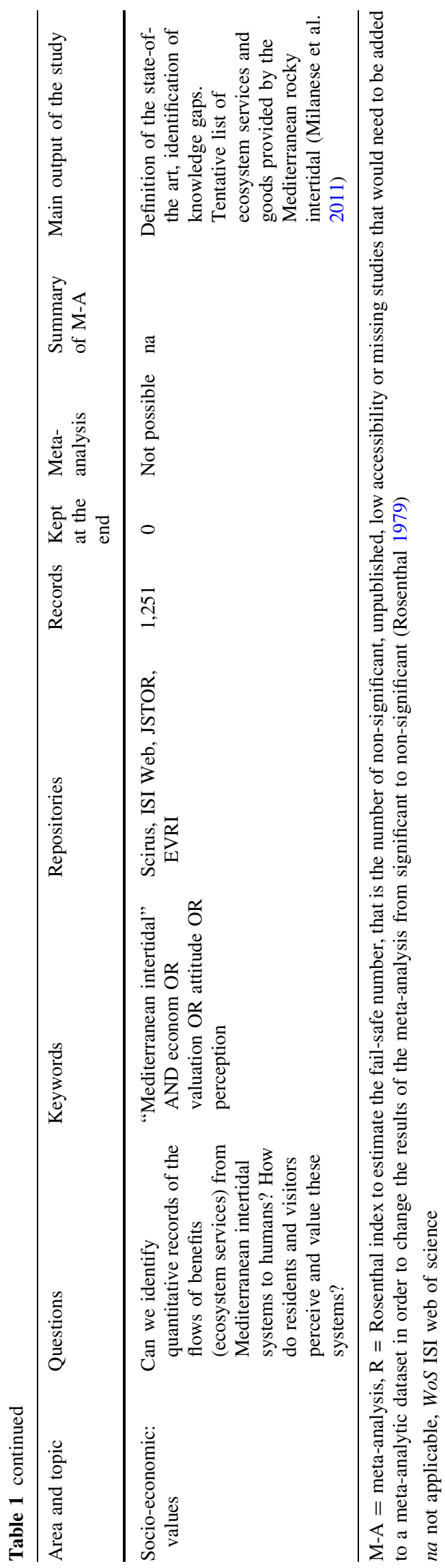

relevant primary data (Table 1). The study revealed a high level of variability in the research that has addressed this topic in terms of species, localities, scope, technique and overall aims. This variability is due to the different goals of the research, which included not only basic but also applied studies of sponge biology (e.g. cultivation, bioremediation). The extreme diversity of the phylum and the complex ecology of sponges harbouring associated micro-organisms further complicate this situation. With no prejudice on the value of the sources retrieved, the literature does not provide evidence-based information to predict responses to climate-change-driven temperature increase, nor advice on the ideal experimental methodology to address this potential threat.

The decision to consider marine gastropods as the target group to review led to mixed outcomes. On the one hand, it allowed for the retrieval of a large number of sources (Table 1). On the other hand, the great number of sources were very heterogeneous and did not allow processing with meta-analytical tools. The future use of more specific questions would allow for more informative research for this group.

Field and laboratory measurements of cellular, ecophysiological and behavioural responses of key Mediterranean intertidal organisms

Thermal range of Mediterranean intertidal rocky habitats Annual temperature fluctuations on an hourly basis measured by thermologgers showed that temperatures ranged from about $5{ }^{\circ} \mathrm{C}$ to over $45^{\circ} \mathrm{C}$ in supratidal habitats, from about $7-10{ }^{\circ} \mathrm{C}$ during low tides in winter at night, to $32-35^{\circ} \mathrm{C}$ during low tides in summer at mid-day in the intertidal (Fig. 1). This dataset was used as the baseline to ground our field and mesocosm experiments, the latter aiming to detect and validate the metabolic break points which would indicate a general collapse of metabolic functioning. No historical information was found concerning temperature fluctuations of Central and Southern Mediterranean intertidal sites. Most available data are from the western (Helmuth et al. 2009) and eastern (Jones et al. 2010) coasts of the United States and from western European coasts (Seabra et al. 2011) with some limited information from eastern Asia (Williams and Morritt 1995). Temperature data suggest intertidal habitats of the Mediterranean are highly stressful for organisms which are frequently pushed far from their tolerance limits. Our results also confirm that air temperatures are not indicative of thermal stress experienced by organisms on rocky substrates, where solar radiation and geothermal heating are likely to be more important in determining the thermal environment the organisms will encounter (substrate temperatures are much higher than air temperatures, Fig. 1, 


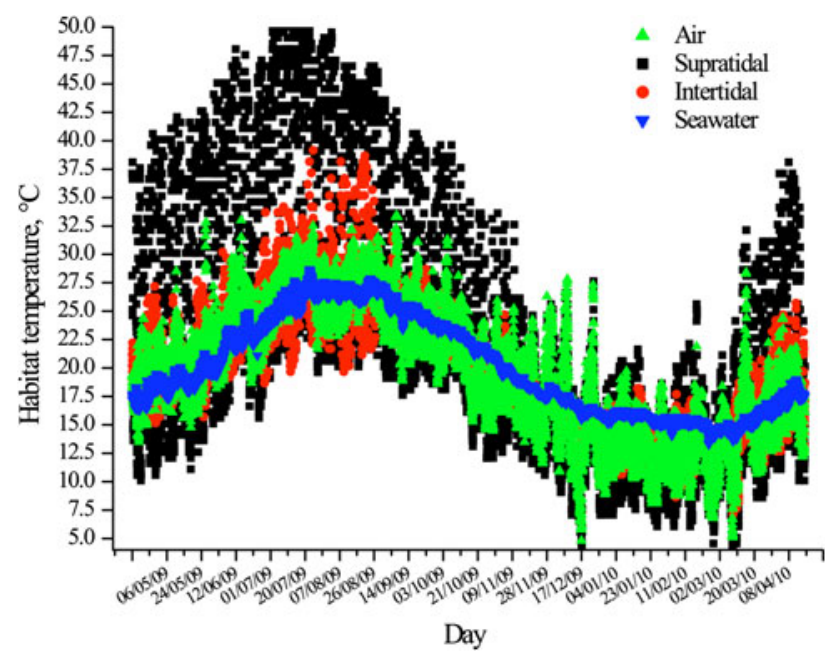

Fig. 1 Thermologger hourly data deployed in several localities of Northern Sicily (Southern Tyrrhenian Sea) showing the thermal limits of intertidal habitats in comparison with supratidal (as expressed by thermologgers deployed higher on the shore), subtidal (as expressed by seawater temperatures) and terrestrial (as expressed by air temperatures)

also see Marshall et al. 2010). This has important repercussions on the fitness of these organisms as these conditions impair physiological and metabolic traits of most ectotherms living on the edge of their tolerance ranges (Somero 2010).

Physiological responses to thermal stress HSP measurements from intertidal snails from Israel showed a clear increase in mean HSP70 values (Fig. 2a) from winter to summer at both Achziv and Palmahim sites, with a more pronounced increase at Achziv. In Achziv, there was a significant correlation between ambient field temperature and HSP70 levels, whereas in Palmachim, this relationship was not present. Although these findings may seem unusual, considering the distance between the two study sites is less than $200 \mathrm{~km}$, we propose that the snails at the northern (Akhziv) site were more susceptible to heat stress than those in the south (Palmachim) as a result of subtle differences in the local climate which are related to factors such as the strength, direction and duration of prevailing winds which can have substantial effects on local coastal temperatures (Helmuth et al. 2002).

Experiments on bivalves in laboratory mesocosms showed that heat shock protein production was induced in B. pharaonis at the lowest tested body temperature $\left(5^{\circ} \mathrm{C}\right.$ HSP; Fig. 2b). The production of HSP70 reached a maximum at $32{ }^{\circ} \mathrm{C}$, corresponding to the beginning of a decline in clearance rate in the invasive bivalve, B. pharaonis (Fig. 4b). The production of HSP90 peaked at $25^{\circ} \mathrm{C}$ and remained constant up to $32{ }^{\circ} \mathrm{C}$. Heart beat rate (HBR) changed significantly as it increased linearly with
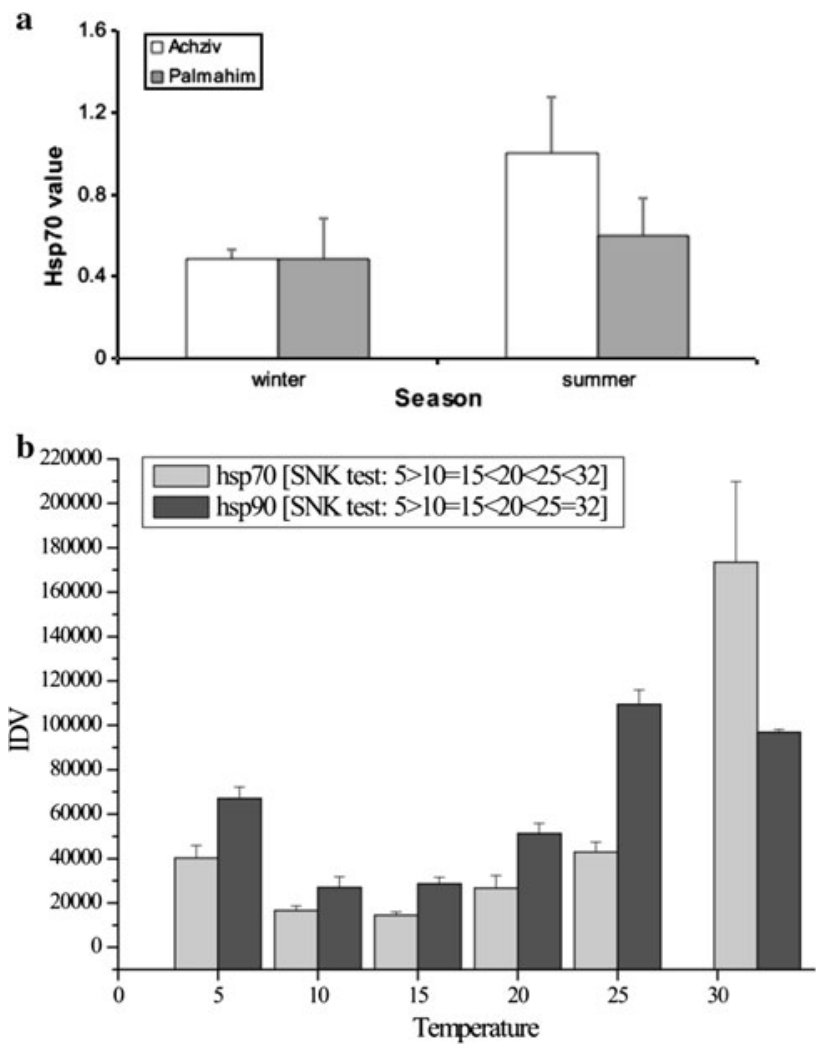

Fig. 2 Measurement of heat shock proteins (HSPs). a HSPs measured (errors bars are standard deviations) in the intertidal snail E. punctata in winter and in summer for Achziv and Palmahim (Israeli coast); b HSPs at various temperatures as measured in bivalves (e.g. B. pharaonis)

temperature in both B. pharaonis and M. minimus (Fig. 3; pooled data due to no significant difference between the two species). There were no differences between HBR in the range $5-15{ }^{\circ} \mathrm{C}$ and no differences between HBR at 20 and $32{ }^{\circ} \mathrm{C}$; however, HBR varied between low and high temperatures $\left(5-15^{\circ} \mathrm{C}\right.$ vs $\left.20-32{ }^{\circ} \mathrm{C}\right)$. The lowest temperature to induce the total arrest of HBR in both $B$. pharaonis and $M$. minimus was $\sim 5^{\circ} \mathrm{C}$. The native species $M$. minimus' heart started to reduce beating at $30{ }^{\circ} \mathrm{C}$, while the invasive $B$. pharaonis $\mathrm{HBR}$ showed no alteration compared to the previous temperature $\left(25^{\circ} \mathrm{C}\right)$. Temperature had a significant effect on feeding rates (CR) and metabolic consumption (respiration rates, $\mathrm{RR}$ ) in both $M$. minimus (Fig. 4a) and B. pharaonis (Fig. 4b). In general, the shape of the species' response curves with respect to temperature was similar, but tolerance limits were significantly different, with Arrhenius break point temperatures estimated for $\mathrm{CR}$ at $\sim 30$ and $\sim 32{ }^{\circ} \mathrm{C}$ respectively; and $\mathrm{RR}$ at $\sim 25$ and $\sim 28{ }^{\circ} \mathrm{C}$, respectively for B. pharaonis and M. minimus.

The sponge $C$. nucula was able to withstand emersion in the low-intertidal zone when canopy-forming algae were present. CR and RR for the sponge showed significant differences between 15 and $19{ }^{\circ} \mathrm{C}$, and between 26 and 


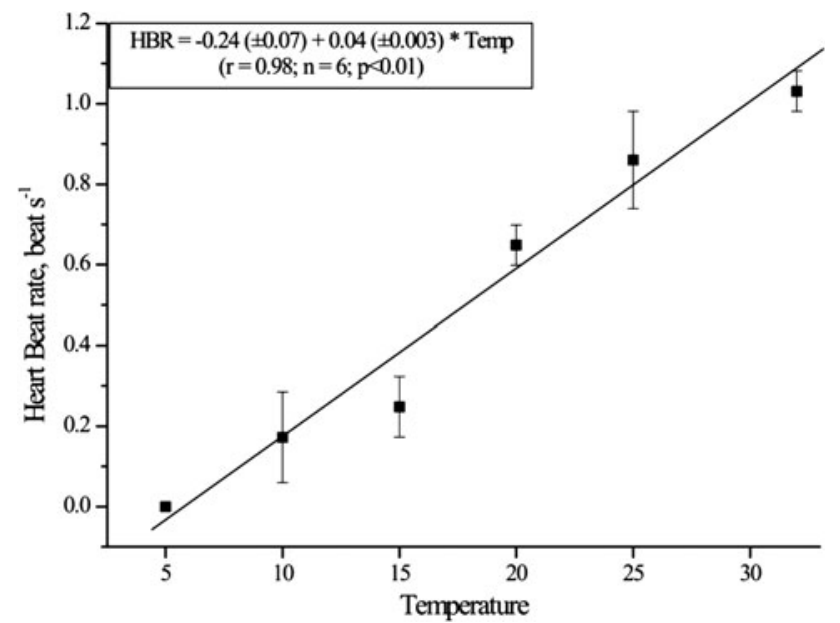

Fig. 3 Relationship between heart beat rate (beat $\mathrm{s}^{-1}$ ) and air temperature in bivalves (data from $M$. minimus and B. pharaonis were pooled due to no significant difference between those two species)
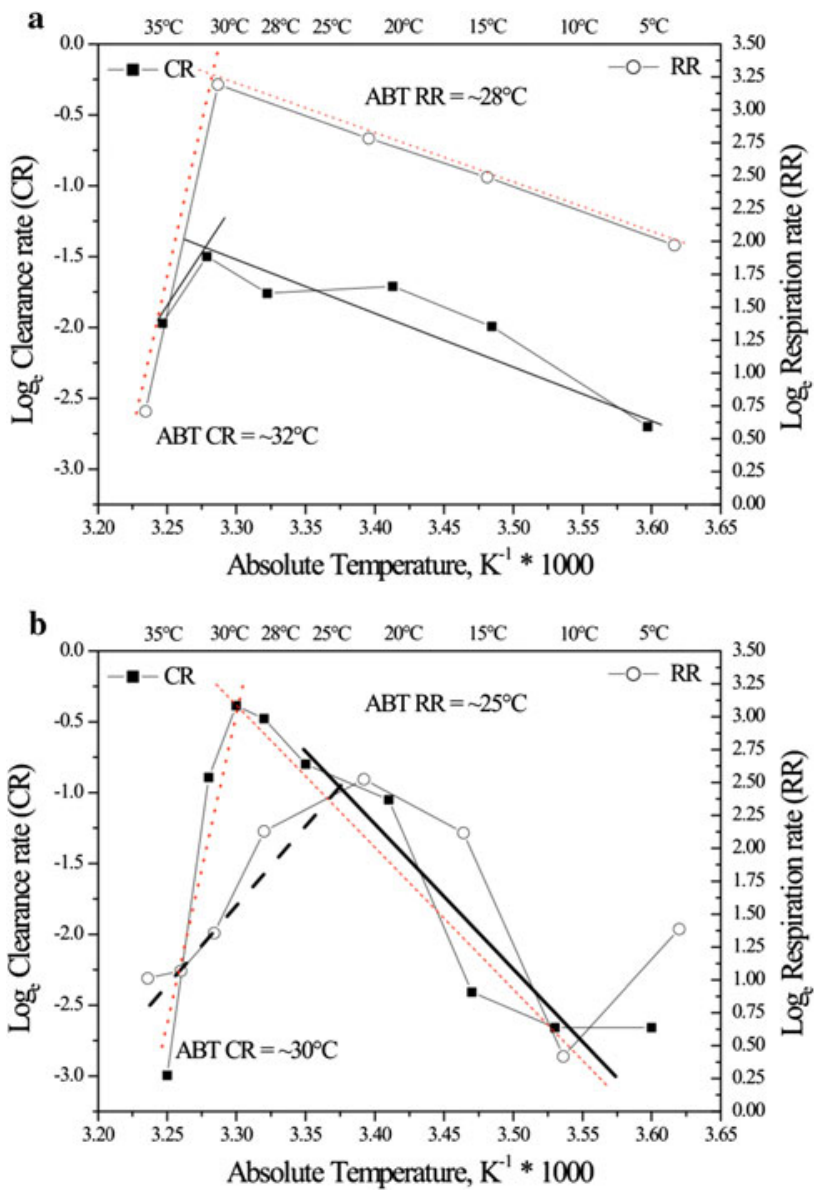

Fig. 4 Relationship between feeding, clearance (CR) and respiration rates (RR) at varying temperatures in $\mathbf{a}$ M. minimus and $\mathbf{b}$ B. pharaonis ( $K$ kelvin temperature; $A B T$ Arrhenius Breakpoint Temperature; that is, the temperature threshold at the metabolic break indicating a general collapse of metabolic functioning; Somero 2010)
$28{ }^{\circ} \mathrm{C}$. Plotting clearance rates versus temperature values showed a normal, bell-shaped curve, with maximum CR between 20 and $26{ }^{\circ} \mathrm{C}$. The relationship between RR and T reflected the typical metabolic response of RR increasing with temperature, with the peak values between 28 and $32{ }^{\circ} \mathrm{C}$ (Fig. 5). Maximum seawater surface temperatures were in August-September 2009 (26-28 ${ }^{\circ} \mathrm{C}$, values from EMIS-Environmental Marine Information System, European Commission). These environmental values are, therefore, still within the physiological limits of $C$. nucula. However, climate-change-driven increases in sea-surface temperature have the potential to impair the physiology of this species, with possible consequences on its vertical and/or geographical distributional range throughout the Basin. Preliminary studies suggest that $C$. nucula may play a structuring role, enhancing biodiversity and partial recovery in benthic communities overgrazed by sea urchins (so-called barrens, Fanelli et al. 2003). Although our physiological findings may not be extended to all Mediterranean sponge species, they confirm the susceptibility of
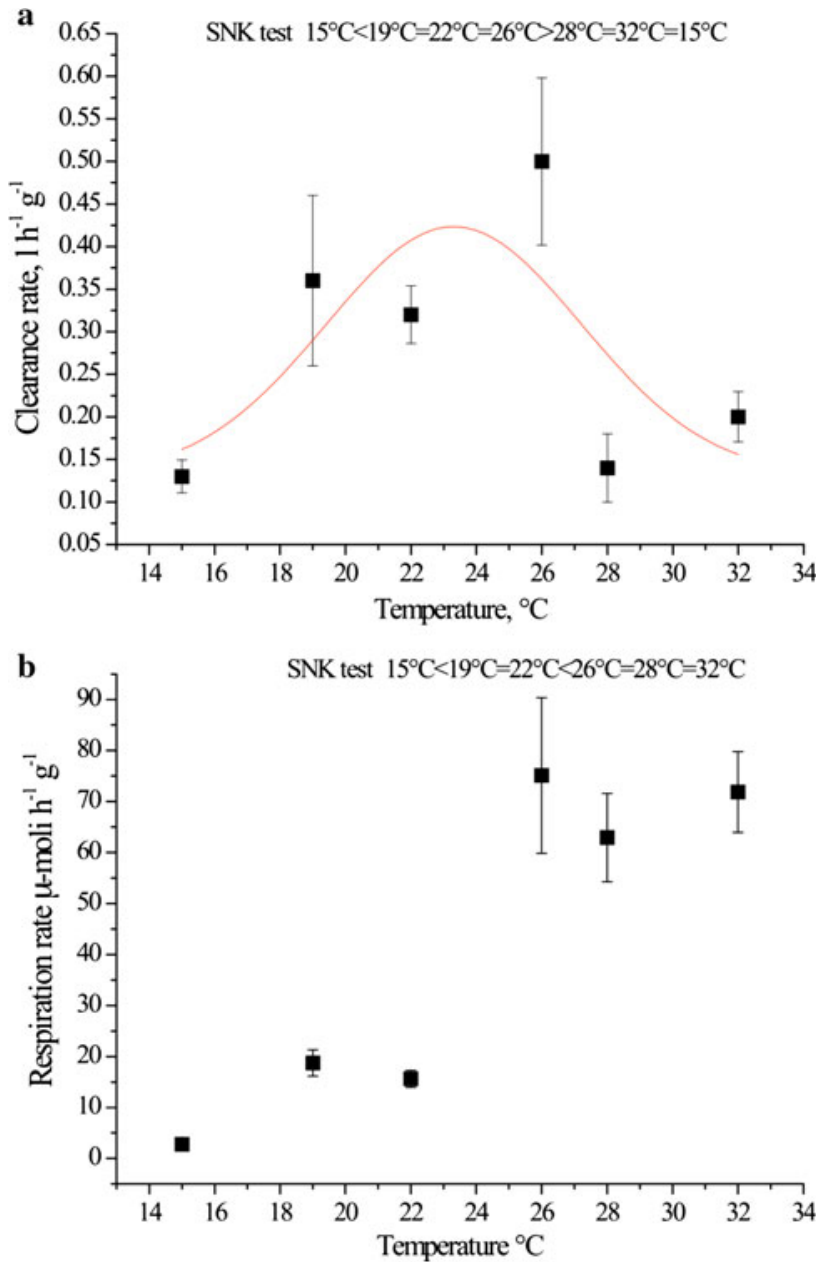

Fig. 5 Relationship between feeding $(\mathrm{CR}$, a) and respiration rates $(\mathrm{RR}, \mathrm{b})$ at varying temperatures in the sponge $C$. nucula 
these organisms to stochastic environmental changes as evidenced by recurring mortality events (Cerrano et al. 2000; Webster 2007; Garrabou et al. 2009).

The limpets $P$. rustica, $P$. caerulea and $P$. aspera occupy different vertical zones on the shore with regard to tidal range, and it is expected they will have different physiological responses to thermal stress. The Arrhenius Breakpoint Temperatures measured in our study showed that $P$. aspera is the most sensitive to temperature increase, as would be expected since it inhabits the lower intertidal zone (Fig. 6). On the other hand, P. rustica, inhabiting the upper intertidal zone, is the most tolerant to temperature rise (Prusina, in preparation; Prusina et al., submitted). However, in spite of a difference in the vertical zones inhabited by these species, the narrow tidal range of the Mediterranean de facto seems to force these organisms to experience similar thermal regimes. Further investigation is therefore needed to determine the relative influence of tidal height on the thermal tolerance, energy allocation and possible chronic impact of temperature stress on these three species.

\section{Ecological modelling}

Ecological modelling could only be implemented for mussels, as only for this group was a sufficient amount of relevant information available following the combination of the two research steps mentioned above. Results of BP-DEB modelling for Italian, Croatian and Israeli localities, simulating the effect of increasing temperature on the Darwinian fitness for native $M$. minimus and invasive B. pharaonis bivalves, indicate that the presence of each species (Table 2a, b) is partly linked to site-specific conditions of availability of food and local body temperature.

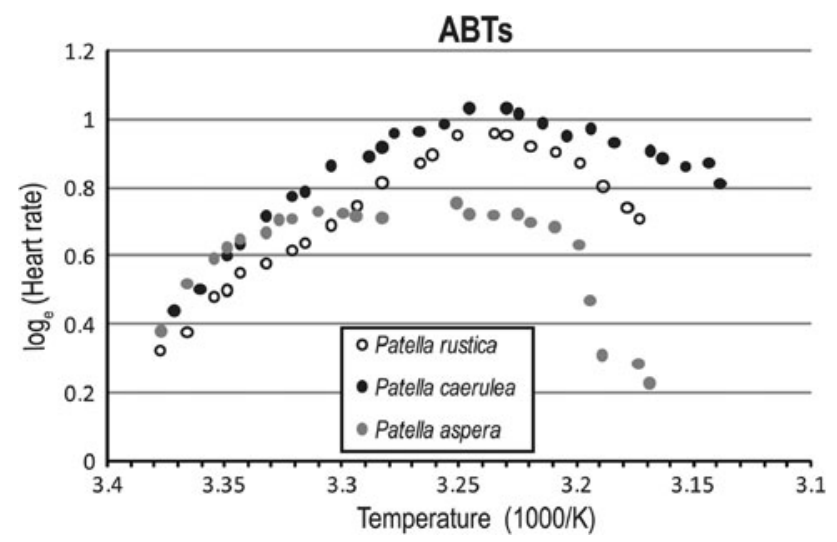

Fig. 6 Breakpoint temperatures (ABT) of heart beat rates for representative individuals of $P$. rustica $\left(37.86 \pm 2.07{ }^{\circ} \mathrm{C}\right), P$. caerulea $\left(35.92 \pm 2.60{ }^{\circ} \mathrm{C}\right)$ and P. aspera $\left(32.20 \pm 2.32{ }^{\circ} \mathrm{C}\right)$ were significantly different (ANOVA, $P=0.007 ; n=5$ for each species) (Prusina, in preparation; Prusina et al., submitted)
While fitness of $M$. minimus tends to reduce with increasing temperature (Table 2b), the invasive Brachidontes shows the opposite trend, in line with recent observations along the Israeli coast (Rilov et al. 2004). In Sicily, the increase in gamete release for the $+1.0{ }^{\circ} \mathrm{C}$ increasing temperature scenario was $\sim 122 \%$ as compared to the current conditions in the Tyrrhenian Sea, and over $220 \%$ for temperatures up $+2.5^{\circ} \mathrm{C}$. Results suggest that in Croatia, B. pharaonis may not be able to maintain viable populations over time, as the simulation suggests this species will not be able to produce eggs, while in Israel, it should be capable of increasing its gonadal output by $\sim 9$ and $27 \%$ for +1.0 and $+2.5^{\circ} \mathrm{C}$ of air and water temperature increase, respectively. This simple example was based on coarse simulations using the simple increase of body temperature. However, the outcome shows how powerful the BP-DEB approach (Kearney et al. 2010; Sarà et al. 2011b; Kearney 2012) can be to investigate the effect of environmental variability induced by climate-change drivers on important elements of Mediterranean benthic biodiversity. This study is one of the very first attempts carried out in aquatic habitats to predict the fitness of animals in the context of climate change (Sarà et al. 2011b). The combined BP-DEB approach could be very useful in this perspective, and we expect that future research on the effects of climate change will rely on similar, mechanistic procedures (Kearney 2012).

Socio-economic study

Collation of relevant literature/databases and metaanalytical review

A thorough systematic review of ecosystem services and benefits from, and values attached to, the Mediterranean intertidal yielded few results (Table 1, Milanese et al. 2011). Even today, in the light of the most recent work published on Mediterranean ecosystem services (Mangos et al. 2010; Salomidi et al. 2012), no further data for the intertidal habitat seem to be available.

\section{Identification of ecosystem services in the Mediterranean intertidal}

In spite of the dearth of knowledge mentioned above, a tentative list of ecosystem services and goods provided by the Mediterranean rocky intertidal ecosystems was compiled (for the first time) on the basis of information especially derived from studies performed outside the Mediterranean basin (Milanese et al. 2011).

When assessing conservation approaches for the intertidal with Israel as a case study, most stakeholders interviewed acknowledged the need to anticipate and manage 
Table 2 Life history traits as estimated under intertidal conditions by running DEB models (the approach was the same as reported in Sarà et al. 2011b) for (A) the invasive bivalve, B. pharaonis and (B) the native bivalve, $M$. minimus at different latitudes for the Mediterranean Basin and under different scenarios (current 2006-2010 vs $+1{ }^{\circ} \mathrm{C}$ vs $+2.5^{\circ} \mathrm{C}$ ) of air and water temperature increase

\begin{tabular}{|c|c|c|c|c|c|c|c|c|c|}
\hline \multirow[t]{2}{*}{ LAT } & \multirow[t]{2}{*}{ LOC } & \multicolumn{2}{|c|}{ Current scenario } & \multirow[t]{2}{*}{$\operatorname{Pr}$} & \multicolumn{2}{|c|}{ Scenario $+1{ }^{\circ} \mathrm{C}$} & \multirow[t]{2}{*}{$\%$} & Scenario $+2.5^{\circ} \mathrm{C}$ & \multirow[t]{2}{*}{$\%$} \\
\hline & & $L_{\max }$ & $R$ & & $L_{\max }$ & $R$ & & $L_{\max }$ & \\
\hline
\end{tabular}

(A)

$\begin{array}{cll}\text { Italy, Tyrrhenian Sea } & \\ 35 & \text { Lampedusa } & 1.01 \\ 37 & \text { Catania } & 0.69 \\ 38 & \text { Palermo } & 0.81 \\ 38 & \text { Stagnone di Marsala } & 1.68 \\ 39 & \text { Palinuro } & 0.97 \\ 41 & \text { Napoli } & 0.74 \\ 43 & \text { Livorno } & 0.82\end{array}$

$\begin{array}{rll}156 & \mathrm{y} & 1.04 \\ 0 & \mathrm{y} & 0.72 \\ 5 & \mathrm{y} & 0.84 \\ 1,443 & \mathrm{y} & 1.74 \\ 318 & \mathrm{y} & 1.00 \\ 0 & \mathrm{n} & 0.76 \\ 43 & \mathrm{n} & 0.85\end{array}$

\begin{tabular}{crr}
175 & 12.67 & 1.08 \\
0.01 & -89.90 & 0.77 \\
37 & 653.69 & 0.88 \\
1,738 & 20.46 & 1.81 \\
372 & 17.38 & 1.04 \\
0.00 & \multicolumn{1}{c}{-} & 0.79 \\
94 & 117.72 & 0.91
\end{tabular}

$\begin{array}{rr}194 & 24.86 \\ 0 & 61.21 \\ 50 & 898.92 \\ 2,253 & 56.12 \\ 445 & 39.99 \\ 0 & - \\ 145 & 234.81\end{array}$

Croatia

0.38

43 Spalato 0.55

Israel

31 South Israel

32 Mid Israel 1.33

33 North Israel $\quad 1.27$

(B)

Italy, Tyrrhenian Sea

\begin{tabular}{|c|c|c|c|c|c|c|c|c|c|c|}
\hline 35 & Lampedusa & 0.72 & 66 & $\mathrm{y}$ & 0.72 & 55 & -16.6 & 0.72 & 46 & -30.3 \\
\hline 37 & Catania & 0.61 & 22 & $\mathrm{y}$ & 0.61 & 17 & -22.7 & 0.62 & 12 & -45.5 \\
\hline 38 & Palermo & 0.60 & 30 & $\mathrm{y}$ & 0.60 & 30 & -0.6 & 0.61 & 30 & -2.4 \\
\hline 39 & Palinuro & 0.65 & 92 & $\mathrm{y}$ & 0.65 & 91 & -0.7 & 0.65 & 84 & -8.4 \\
\hline 41 & Napoli & 0.58 & 35 & $\mathrm{y}$ & 0.58 & 38 & 7.3 & 0.59 & 40 & 12.5 \\
\hline 43 & Livorno & 0.77 & 55 & $\mathrm{y}$ & 0.78 & 60 & 8.1 & 0.80 & 86 & 55.2 \\
\hline \multicolumn{11}{|c|}{ Croatia } \\
\hline 42 & Dubrovnik & 0.43 & 0 & $\mathrm{n}$ & 0.44 & 0 & - & 0.44 & 0 & - \\
\hline 43 & Spalato & 0.59 & 25 & $\mathrm{n}$ & 0.6 & 28 & 12.0 & 0.6 & 30 & 20.0 \\
\hline \multicolumn{11}{|c|}{ Israel } \\
\hline 31 & South Israel & 0.82 & 159 & $\mathrm{y}$ & 0.82 & 138 & -12.84 & 0.83 & 127 & -20.13 \\
\hline 32 & Mid Israel & 0.87 & 206 & $\mathrm{y}$ & 0.87 & 178 & -13.43 & 0.88 & 163 & -20.76 \\
\hline 33 & North Israel & 0.84 & 206 & $\mathrm{y}$ & 0.85 & 163 & -20.79 & 0.85 & 177 & -14.13 \\
\hline
\end{tabular}

LAT $=$ latitude, LOC $=$ locality, $L_{\max }, \mathrm{cm}=$ total length maximally reachable under specific conditions of temperature and food availability; $R$, \# eggs = the Darwinian fitness, that is, number of eggs, produced per gram of body mass per life span (4-years); $\%=$ incremental change in fitness as expressed by the increasing number of eggs with respect to the current 2006-2010; $\mathrm{Pr}=$ presence in the intertidal; $y=$ ascertained presence in the intertidal through literature or anecdotal reporting; $\mathrm{n}=$ not ascertained presence in the intertidal. Since the Stagnone di Marsala is a hyperaline area, DEB was run only for B. pharaonis according to Sarà et al. (2008) and Sarà and De Pirro (2011)

climate-change impacts generally, but had little awareness of the intertidal zone and the ecosystem services it provides. Not surprisingly, there was little or no specific provision for managing intertidal communities besides the general conservation frameworks implemented in the existing protected areas. Currently, only a very limited share of the Israeli Mediterranean coast is protected, but plans for a significant increase are under way. When speaking of broad conservation frameworks, all stakeholders interviewed indicated that marine-protected areas
(MPA) are a preferred direction. This direction was significant since, although MPAs are the workhorse of the conservation community, in some cases, they have been shown to be inadequate for the needs of the intertidal zone (Hall et al. 2002). This has serious implications for dominant bio-geomorphological features of the coast such as Vermetid reefs as they are very sensitive to climate-change impacts, for example wave erosion (Safriel 1974; Tzur and Safriel 1978; Chemello and Silenzi 2011) and require protection. There also appeared to be very little interaction 
among different stakeholders with interests in the intertidal zone (i.e. conservation and non-conservation), and this highlights the potential for conflict in identifying priorities, developing policy and implementing it effectively.

\section{Conclusions}

The present study highlights the significant knowledge gaps in our understanding of the ecophysiological and socio-economic characteristics of the Mediterranean intertidal zone. These knowledge gaps hamper our ability to predict the susceptibility of the Mediterranean intertidal to climate change, and any derived socio-economic consequences. Nevertheless, and building upon the research undertaken to improve such limited understanding, results indicate that climate change (and in particular temperature increase) will impact Mediterranean intertidal ecosystems by impairing the physiology of key-organisms and favouring the survival of alien, invasive species. Further studies ranging from basic physiological measurements up to the testing of cascade-effects are, therefore, necessary to predict and quantify these impacts. Furthermore, the study highlighted the limited knowledge of the socio-economic processes which are important to understand the benefits associated with intertidal ecosystems.

We recommend that a more exhaustive list of benefits be compiled and associated values estimated, which would promote a more effective management strategy, including conservation approaches which consider longer-term trends in climate.

Acknowledgments This paper has been inspired and sustained by INTERMED, one of the CIRCLE Med projects funded by the French Ministry of Ecology, Energy, Sustainable Development and Territorial Planning, the Regional Ministry of Innovation and Industry of the Galician Government, the Ministry of Environment Protection of Israel, the Italian Ministry for Environment, Land and Sea, and the Foundation for Science and Technology of Portugal, in the framework of Circle ERA Net project (which is funded by the European Commission 6th Framework Programme). We thank and are especially grateful to all collaborators and students from all laboratories and teams involved in this project.

\section{References}

Aburto-Oropeza O, Ezcurra E, Danemann G, Valdez V, Murray J, Sala E (2008) Mangroves in the Gulf of California increase fishery yields. Proc Natl Acad Sci USA 105:10456-10459

Barbier EB (2000) Valuing the environment as an input: review of applications to mangrove-fishery linkages. Ecol Econ 35:47-61

Barbier EB, Hacker SD, Kennedy CE, Koch W, Stier AC, Silliman BR (2011) The value of estuarine and coastal ecosystem services. Ecol Monogr 81:169-193

Bell JJ (2008) The functional roles of marine sponges. Estuar Coast Shelf Sci 79:341-353
Cerrano C, Bavestrello G, Bianchi CN, Cattaneo-Vietti R, Bava S, Morganti C, Morri C, Picco P, Sara G, Schiaparelli S, Siccardi A, Sponga F (2000) A catastrophic mass-mortality episode of gorgonians and other organisms in the Ligurian Sea (Northwestern Mediterranean), summer 1999. Ecol Lett 3:284-293

Chemello R, Silenzi S (2011) Vermetid reefs in the Mediterranean Sea as archives of sea-level and surface temperature changes. Chem Ecol 27:121-127

Depledge MH, Andersen BB (1990) A computer-aided physiological monitoring system for continuous, long-term recording of cardiac activity in selected invertebrates. Comp Biochem Physiol 96:473-477

Doney SC, Ruckelshaus M, Duffy JE, Barry JP, Chan F, English CA, Galindo HM, Grebmeier JM, Hollowed AB, Knowlton N, Polovina J, Rabalais NN, Sydeman WJ, Talley LD (2012) Climate change impacts on marine ecosystems. Ann Rev Mar Sci 4:11-37

Dong YW, Williams GA (2011) Variations in cardiac performance and heat-shock protein expression to thermal stress in two differently zoned limpets on a tropical rocky shore. Mar Biol 158:1223-1231

Ezgeta-Balic D, Rinaldi A, Peharda M, Prusina I, Montalto V, Niceta N, Sarà G (2011) An energy budget of the subtidal bivalve, Modiolus barbatus (Mollusca) at different temperatures. Mar Environ Res 71:79-85

Fanelli G, Portacci G, Boero F (2003) Patches of Chondrilla nucula: high-biodiversity spots within low-biodiversity barrens. In: Proceedings of the 38th European marine biology symposium, Aveiro, September 8-12 2003, abstract book: 115-116

Garrabou J, Coma R, Bensoussan N, Bally M, Chevaldonne P, Cigliano $M$ et al (2009) Mass mortality in Northwestern Mediterranean rocky benthic communities: effects of the 2003 heat wave. Glob Change Biol 15:1090-1103

Hall D, Hall J, Murray S (2002) Contingent valuation of marine protected areas: Southern California Rocky intertidal ecosystems. Nat Resour Model 15:3

Halpin PM, Sorte CJ, Hofmann GE, Menge BA (2002) Patterns of variation in levels of $\mathrm{Hsp} 70$ in natural rocky shore populations from microscales to mesoscales. Integr Comp 42:815-824

Harley CDG, Hughes AR, Hultgren K, Miner BG, Sorte CJB, Thornber CS, Rodriguez LF, Tomanek L, Williams SL (2006) The impacts of climate change in coastal marine systems. Ecol Lett 9:228-241

Helmuth BST (1998) Intertidal mussel microclimates: predicting the body temperature of a sessile invertebrate. Ecol Monogr 68:51-74

Helmuth BST (1999) Thermal biology of rocky intertidal mussels: quantifying body temperatures using climatological data. Ecology 80:15-34

Helmuth BST, Harley CDG, Halpin P, O’Donnell M, Hofmann GE, Blanchette C (2002) Climate change and latitudinal patterns of intertidal thermal stress. Science 298:1015-1017

Helmuth BST, Mieszkowska N, Moore P, Hawkins SJ (2006) Living on the edge of two changing worlds: forecasting the response of rocky intertidal ecosystems to climate change. Annu Rev Ecol Evol Syst 37:373-404

Helmuth BST, Broitman BR, Yamane L, Gilman SE, Mach K, Mislan KAS, Denny MW (2009) Organismal climatology: analyzing environmental variability at scales relevant to physiological stress. J Exp Biol 213:995-1003

Herr D, Galland GR (2009) The ocean and climate change. Tools and guidelines for action. IUCN, Gland

IPCC (2007) Climate change 2007 contribution of working groups I, II and III to the fourth assessment report of the intergovernmental panel on climate change core writing team. In: Pachauri RK, Reisinger A (eds) IPCC, Geneva, Switzerland 
Jones SJ, Lima FP, Wethey DS (2010) Rising environmental temperatures and biogeography: poleward range contraction of the blue mussel, Mytilus edulis L., in the western Atlantic. J Biogeogr 37:2243-2259

Kareiva P, Tallis H, Ricketts TH, Daily GC, Polasky S (2011) Theory and practice of mapping ecosystem services. Oxford University Press, Oxford

Kearney M (2012) Metabolic theory, life history and the distribution of a terrestrial ectotherm. Funct Ecol 26:167-179

Kearney M, Simpson SJ, Raubenheimer D, Helmuth BST (2010) Modelling the ecological niche from functional traits. Proc R Soc B Biol Sci 365:3469-3483

Kearney M, Matzelle A, Helmuth BST (2012) Modelling the biomechanics meets the ecological niche: the importance of temporal data resolution. J Exp Biol 215:922-933

Kooijman SALM (2010) Dynamic energy budget theory for metabolic organisation, 3rd edn. Cambridge University Press, Cambridge

Mangos A, Bassino J-P, Sauzade D (2010) The economic value of sustainable benefits rendered by the Mediterranean marine ecosystems, Plan Bleu, Valbonne (Blue Plan Papers) 8. http://www.planbleu.org/publications/Cahier8_marin_EN.pdf

Marcos M, Tsimplis MN (2009) Comparison of results of AOGCMs in the Mediterranean Sea during the 21st century. J Geophys Res. doi:10.1029/2008JC004820

Marshall DJ, McQuaid CD, Williams GA (2010) Non-climatic thermal adaptation: implications for responses to climate change. Biol Lett 6:669-673

Milanese M, Sarà A, Sarà G, Murray J (2011) Climate change, marine policy and the valuation of Mediterranean intertidal ecosystems. Chem Ecol 27:95-105

Millennium Ecosystem Assessment (2005) Ecosystems and human well-being: current state and trends, vol I. Island Press, Washington, DC

Nagelkerken I, van der Velde G, Gorissen MW, Meijer GJ, Van't Hof $\mathrm{T}$, den Hartog C (2000) Importance of mangroves, seagrass beds and the shallow coral reefs as nursery for important coral reef fishes, using a visual census technique. Estuar Coast Shelf Sci $51: 31-44$

Nixon SW (2009) Eutrophication and the macroscope. Hydrobiologia 629:5-19

Palmeri V (2011) Ecological responses of marine bivalves to anthropogenic pressure. A bioenergetic approach. PhD Dissertation, University of Palermo

Pusceddu A, Sarà G, Mazzola A, Fabiano M (1997) Relationships between suspended and sediment organic matter in a semienclosed marine system: the Stagnone di Marsala sound (Western Sicily). Water Air Soil Pollut 99:343-352

Rilov G, Benayahu Y, Gaisth A (2004) Prolonged lag in population outbreak of an invasive mussel: a shifting-habitat model. Biol Invasions 6:347-364

Rosenthal R (1979) The "file drawer problem" and tolerance for null results. Psychol Bull 86:638-641

Safriel UN (1974) Vermetid gastropods and intertidal reefs in Israel and Bermuda. Science 186:1113-1115

Salomidi M, Katsanevakis S, Borja Á, Braeckman U, Damalas D, Galparsoro I, Mifsud R, Mirto S, Pascual M, Pipitone C, Rabaut M, Todorova V, Vassilopoulou V, Vega Fernandez T (2012) Assessment of goods and services, vulnerability, and conservation status of European seabed biotopes: a stepping stone towards ecosystem-based marine spatial management. Med Mar Sci 13(1):49-88

Sarà G (2006) Hydrodynamic effect on the origin and quality of organic matter for bivalves: an integrated isotopic, biochemical and transplant study. Mar Ecol Prog Ser 328:65-73
Sarà G (2007a) A meta-analysis on the ecological effects of aquaculture on the water column: dissolved nutrients. Mar Environ Res 63:390-408

Sarà G (2007b) Ecological effects of aquaculture on living and nonliving suspended fractions of the water column: a meta-analysis. Water Res 41:3187-3200

Sarà G (2009) Variation of suspended and sedimentary organic matter with depth in shallow coastal waters. Wetlands 29:1234-1242

Sarà G, De Pirro M (2011) Heart beat rate adaptations to varying salinity of two intertidal Mediterranean bivalves: the invasive Brachidontes pharaonis and the native Mytilaster minimus. Ital J Zool 78:193-197

Sarà G, Mazzola A (2004) The carrying capacity for Mediterranean bivalve suspension feeders: evidence from analysis of food availability and hydrodynamics and their integration into a local model. Ecol Model 179:281-296

Sarà G, Romano C, Caruso M, Mazzola A (2000) The new Lessepsian entry Brachidontes pharaonis (Fischer P., 1870) (Bivalvia, Mytilidae) in the western Mediterranean: a physiological analysis under varying natural conditions. J Shellfish Res 19:967-977

Sarà G, Romano C, Widdows J, Staff FJ (2008) Effect of salinity and temperature on feeding physiology and scope for growth of an invasive species (Brachidontes pharaonis-MOLLUSCA: BIVALVIA) within the Mediterranean sea. J Exp Mar Biol Ecol 363:130-136

Sarà G, Kearney M, Helmuth B (2011a) Combining heat-transfer and energy budget models to predict local and geographic patterns of mortality in Mediterranean intertidal mussels. Chem Ecol 27:135-145

Sarà G, Lo Martire M, Sanfilippo M, Pulicanò G, Cortese G, Mazzola A, Manganaro A, Pusceddu A (2011b) Impacts of marine aquaculture at large spatial scales: evidences from $\mathrm{N}$ and $\mathrm{P}$ catchment loading and phytoplankton biomass. Mar Environ Res 71:317-324

Sarà $\mathrm{G}$, Sarà $\mathrm{A}$, Milanese $\mathrm{M}(2011 \mathrm{c})$ The Mediterranean intertidal habitat as a natural laboratory to study climate change drivers of geographic patterns in marine biodiversity. Chem Ecol 27:91-93

Sarà G, Reid G, Rinaldi A, Palmeri V, Troell M, Kooijman SALM (2012) Growth and reproductive simulation of candidate shellfish species at fish cages in the southern Mediterranean: dynamic energy budget (DEB) modelling for integrated multi-trophic aquaculture. Aquaculture 324-325:259-266

Scheiner SM, Gurevitch J (2001) Design and analysis of ecological experiments. Oxford University Press, New York

Scyphers SB, Powers SP, Heck KL, Byron D (2011) Oyster reefs as natural breakwaters mitigate shoreline loss and facilitate fisheries. PLoS ONE 6:e22396

Seabra R, Wethey DS, Santos AM, Lima FP (2011) Side matters: microhabitat influence on intertidal heat stress over a large geographical scale. J Exp Mar Biol Ecol 400:200-208

Somero GN (2010) The physiology of climate change: how potentials for acclimatization and genetic adaptation will determine 'winners' and 'losers'. J Exp Biol 213:912-920

Tomanek L, Somero GN (2002) Interspecific and acclimationinduced variation in levels of heat-shock proteins 70 (hsp70) and 90 (hsp90) and heat-shock transcription factor-1 (HSF1) in congeneric marine snails (genus Tegula): implications for regulation of hsp gene expression. J Exp Biol 205:677-685

Townsend M, Thrush SF, Carbines MJ (2011) Simplifying the complex: an 'Ecosystem Principles Approach' to goods and services management in marine coastal ecosystem. Mar Ecol Prog Ser 434:291-301

Tzur Y, Safriel UN (1978) Vermetid platforms indicators of coastal movements. Israel J Earth Sci 27:124-127 
Webster N (2007) Sponge disease: a global threat? Environ Microbiol 9(6):1363-1975

Wethey DS, Woodin SA (2008) Ecological hindcasting of biogeographic responses to climate change in the European intertidal zone. Hydrobiologia 606:139-151

Williams GA, Morritt D (1995) Habitat partitioning and thermal tolerance in a tropical limpet, Cellana grata on a tropical rocky shore. Mar Ecol Prog Ser 124:89-103

Williams GA, De Pirro M, Cartwright SR, Khangura HK, Ng WC, Leung TY, Morritt D (2011) Come rain or shine: the combined effects of physical stresses on physiological and protein-level responses of an intertidal limpet in the monsoonal tropics. Funct Ecol 25:101-110

Wilson MA, Costanza R, Boumans R, Liu S (2005) Integrated assessment and valuation of ecosystem goods and services provided by coastal systems. In: Wilson JG (ed) The intertidal ecosystem - the value of Ireland's shore. Royal Irish Academy, Dublin 